\title{
BENEFITS AND THREATS RELATED TO THE FUNCTIONING OF POLISH TOURIST COMPANIES AGAINST THE BACKGROUND OF THE LIBERALISATION OF THE SERVICES MARKET
}

\author{
ANNA DĄBROWSKA, ${ }^{1}$ MIROSŁAWA JANOŚ-KRESŁO ${ }^{2}$ \\ ${ }^{1}$ Institute for Market, Consumption and Business Cycles Research, POLAND \\ e-mail: annadabrowska1@wp.pl \\ ${ }^{2}$ Warsaw School of Economics, POLAND \\ e-mail:mjanos@sgh.waw.pl
}

\begin{tabular}{l|l} 
RECEIVED & 14 August 2017 \\
ACCEPTED & 15 December 2017 \\
JEL & \\
CLASSIFICATION & D22, F23
\end{tabular}

KEYWORDS the liberalisation of the services market, polish tourist companies, benefits and threats

ABSTRACT The liberalisation of the services market, which affects also tourist services, aims at the transformation of the economic structure, increasing economic efficiency and economic development. The tourism sector of economic activity has the potential to stimulate economic growth and increase employment in the EU simultaneously contributing to the economic and social development and integration. The objective of this article is to present the findings of the quantitative research related to the discussed issue, i.e. the benefits and threats related to the functioning of Polish tourist businesses in the European Union markets in the era of liberalization of the services market. In the article the authors have used source literature, secondary data as well as the findings of a study carried out as part of a research project financed by the National Science Centre (NCN) 2015/17/B/HS4/02750 "Liberalization of the services market in the EU as a factor increasing the innovativeness and competitiveness of Polish service companies".

\section{Introduction}

The economic integration of Europe creates opportunities to change conditions of rendering services in the territory of the European Union, including Poland, which is also confirmed by the authors' empirical research. The liberalisation of the services market, which affects also tourist services, aims at the transformation of the economic structure, increasing economic efficiency and economic development. 
The main sources of law related to rendering services in the territory of the European Union are the Treaty on the Functioning of the European Union (Art. 56) (The Treaty..., 2012), the Directive 2006/123/EC of the European Parliament and the Council of 12 December 2006 on the internal services market, the so-called Services Directive (Directive.., 2006). The Treaty provides for the general principle of freedom to render services. This implies a prohibition on the restriction of freedom to provide services within the EU in relation to nationals of the Member States who are owners of businesses in the Member State other than that of the client, i.e. the recipient of the service. In turn, the Services Directive aims at facilitating entrepreneurship by eliminating administrative and legal barriers, simplifying the system of providing cross-border services in other EU countries, enabling entrepreneurs to obtain information and fulfil administrative procedures in one place in each country. The Services Directive is also important for consumers because it gives them the opportunity to choose from a wider, more diversified offer, both in terms of price and quality, and it provides easier access to services throughout the EU. The Services Directive refers, among others, to tourist services.

The tourism sector should fully benefit from the integration of the European services market. Tourism is an important and modern sphere of the economic activity; it is one of the basic measures of the standard of living of societies as well as an indicator of their civilizational development. The tourism sector of economic activity has the potential to stimulate economic growth and increase employment in the EU simultaneously contributing to the economic and social development and integration.

Europe has strengthened its position as the most popular tourist destination in the world. The travellers' arrivals in Europe in 2016 increased to 620 million, which represents an annual increase of $2 \%$. The dynamics of the tourist traffic to particular regions of Europe were diversified, which was the reflection of the risk related to the safety of tourists. The tourists' arrivals to Northern Europe increased by $6 \%$, and to Central European countries by $4 \%$, to Southern Europe by 1\%, and to Western Europe, they remained at the same level as last year (Sustained..., 2017).

As Taleb Rifai, the Secretary General of UNWTO, said, "As we celebrate 2017 as the International Year of Sustainable Tourism for Development, we welcome the continued development of tourism and recall that with growth comes increased responsibility to ensure tourism can contribute to sustainability in all its three pillars economic, social and environmental" (World..., 2017).

Tourism in the EU is mainly of inter-European character. In recent years, one may observe a growing importance of several days' and single-day travel and the use of accommodation in small motels and hotel facilities, as well as growing importance of the Internet for reservations and travel planning.

In the last years, the European Union has made a major contribution to creating a European tourism policy. Much attention is being given to factors which are decisive for its competitiveness as well as to the requirements of sustainable development. The entry into force of the Treaty of Lisbon has highlighted the role of tourism, while the EU has been empowered to support, coordinate and supplement the activity undertaken by the Member States. This represents significant progress, brings the necessary transparency and facilitates a coherent framework for action (Europe..., 2010).

It is worth noting that the European Commission recognizing the changes taking place in tourism and with the purpose of more detailed monitoring of new phenomena in this sphere of activity took a new initiative in 2011 with regard to creating a new regulation harmonizing the procedures for preparing and collecting statistical data concerning tourism services (Regulation..., 2011). 


\section{Liberalisation of the services market as an opportunity for the internationalization of Polish service companies}

Since the introdction of the single internal market, Europe has changed as a result of the reunification, expansion and greater integration. (Fabrini, 2015; Engan, 2015).

The freedom to provide services and the freedom to establish companies are fundamental freedoms of the European single market. Pursuant to the Article 57 of the Treaty on the Functioning of the European Union - TFUE, "services shall be considered to be 'services' within the meaning of the Treaties where they are normally provided for remuneration, in so far as they are not governed by the provisions relating to freedom of movement for goods, capital and persons". The legal basis of the freedom to provide services are articles 57-62 TFUE and the Services Directive from 2006.

Addressing the problem of the share of services in the integration process one should relate it to the creation of the internal services market, as reflected in the Lisbon Strategy. In this strategy, the European Commission has highlighted three key areas: the competitiveness of companies (services increasingly determine the competitiveness of enterprises), innovations (knowledge enhances services, raises the standard of services, enables and stimulates the development of modern technologies), globalization of the market (the development of e-services and information society).

\section{Research methodology}

Searching for answers to questions concerning the benefits and barriers (both administrative and regulatory) for Polish service companies resulting mainly from the liberalisation of the services market, and especially from the transposition of the Services Directive, and also whether the implemented solutions affect the competitiveness and innovativeness of Polish service companies requires carrying out desk research and also planning quantitative and qualitative research. Quantitative research has been conducted by means of the "face to face" method with the application of a survey questionnaire in December 2016.

The respondents were Polish service companies providing services covered by the Services Directive in the territory of the EU countries. The research has been preceded by the pilot study carried out in accordance with the ESOMAR International Code of Market Research and Social Research. 400 enterprises taking part in the research operated in all markets of the European Union, however, most frequently they rendered services in such countries as: Germany (64\% indications), France (29\%), Italy (29\%), Czech Republic (28\%), the Netherlands (23\%), Great Britain (22\%) and Spain (21\%). 70 enterprises (17.5\%) represented the group operating in the tourism, accommodation and catering sectors, including enterprises: small $-79 \%$, medium $-14 \%$, large $-7 \%$.

The objective of this article is to present the findings of the quantitative research related to the discussed issue, i.e. the benefits and threats related to the functioning of Polish tourist businesses in the European Union markets in the era of liberalization of the services market.

\section{Benefits and threats related to the activity of tourist enterprises in the markets of other countries of the Europern Union}

The examined enterprises, which operated in other markets of the European Union for at least 2 years, have obtained the experience which allowed them to point to the relevant benefits and threats. The distinguished factors 
were assigned specific scores from 0 to 5 points, where 5 represented the highest importance; 4 - high importance; 3 - moderate importance; 2 - low importance; 1 - very low importance; 0 - no importance.

Taking into account the significance of the benefits for Polish tourist enterprises as felt by respondents, one may point to the benefits with large (highest and high) importance, moderate and low (low and very low) importance (Table 1).

Table 1. Benefits and threats related to the functioning of Polish tourist enterprises in the EU markets

\begin{tabular}{|c|c|c|c|c|c|}
\hline \multirow[t]{2}{*}{ Benefits } & \multicolumn{2}{|c|}{$\begin{array}{l}\text { Percentage } \\
\text { of indications }\end{array}$} & \multirow[t]{2}{*}{ Threats } & \multicolumn{2}{|c|}{$\begin{array}{l}\text { Percentage } \\
\text { of indications }\end{array}$} \\
\hline & A & B & & A & $\mathrm{B}$ \\
\hline Larger market & 21 & 58 & Still too much bureaucracy & 19 & 43 \\
\hline Opportunity to win new orders & 14 & 55 & Changing exchange rates & 35 & 27 \\
\hline Opportunity to develop the business & 8 & 45 & Too high costs & 35 & 19 \\
\hline Increased efficiency & 20 & 45 & Too much competition & 25 & 27 \\
\hline Possibility to increase turnover & 17 & 46 & No support from the state administration & 30 & 27 \\
\hline Possibility to win new customers & 24 & 47 & Considerable influx of foreign companies & 29 & 23 \\
\hline Possibility of establishing new business contacts & 15 & 37 & Problems with payment for the rendered services & 36 & 25 \\
\hline Possibility to expand the services range & 21 & 31 & Too complicated regulations & 31 & 15 \\
\hline Higher prices on the European market & 18 & 36 & Language barriers & 28 & 24 \\
\hline Access to information via the Single Contact Point & 18 & 35 & Complex provisions & 32 & 12 \\
\hline Marketing benefits & 30 & 33 & Too high expectations of employees & 30 & 24 \\
\hline Faster access to information on contractors & 18 & 26 & The imbalance between quality and price & 40 & 24 \\
\hline Possibility to draw from the experience of others & 30 & 23 & Other standards of rendering services & 24 & 16 \\
\hline Faster ways of dealing with formalities & 36 & 22 & Eastern European markets are very difficult & 32 & 20 \\
\hline Simplification of tax obligations & 33 & 27 & Limited access to information & 24 & 17 \\
\hline Easier access to suitable workforce & 30 & 21 & Gap in technological development & 46 & 23 \\
\hline The possibility to simplify procedures & 48 & 20 & Western EU markets are very difficult & 33 & 16 \\
\hline Better information inflow & 23 & 22 & $\begin{array}{l}\text { Insufficient promotion of Polish service providers } \\
\text { and the economy }\end{array}$ & 32 & 14 \\
\hline $\begin{array}{l}\text { Learning the language of the country where the } \\
\text { service is provided }\end{array}$ & 34 & 23 & Polish people are seen as cheap labour force & 32 & 16 \\
\hline Reducing bureaucratic procedures & 33 & 20 & Perceiving the Poles as worse service providers & 41 & 23 \\
\hline & & & Low openness of customers to Polish companies & 35 & 7 \\
\hline
\end{tabular}

A - very low and low importance; B - high and highest importance.

Source: the authors' own research 2017.

It may be stated that the greatest benefits of providing services in the territory of other countries are seen mainly in the context of a widely perceived development of the activity - increasing the market, obtaining new orders and winning new clients, increasing revenue, increased efficiency, the development of the company and marketing benefits. The responses concerning the possibility to export services in the form of trans-border services (66\%) and the possibility of establishing branches of companies and outlets in other countries (76\%) appear to support this claim.

The perceived benefits which are of moderate importance for the respondents are: the possibility to establish business contacts, higher prices in the European market, learning the language of the country where the services 
are provided, the possibility to draw on the experience of others, better flow of information, decreasing bureaucratic procedures, the possibility to expand services range, easier access to suitable workforce, faster access to information on contractors. The issues connected with procedures - the possibility of establishing procedures, faster ways of dealing with formalities, and also simplification of tax obligations. The benefits which were seen as having no importance (the highest ratio of indications - 16\%) were: the possibility to simplify procedures, faster ways of dealing with formalities and faster information on contractors (13\%). The remaining indications did not exceed $10 \%$.

In respondents' view, the greatest threat is excessive bureaucracy. Other threats were seen as less important. The aspects which were seen as threats of moderate importance were: greater competition, no support from the state, administration, language barriers, other standards of providing services, low openness of clients to Polish companies, very difficult Western EU markets, insufficient promotion of Polish service providers and economy, the perception of Poles as cheap labour force, unclear regulations, complicated provisions, too high competition and limited access to information. The factors seen as threats of low importance were: changes in currency exchange rates, too high expectations on the part of labour force, perception of Polish entities as worse service providers, gap in the technological development, the fact that Eastern EU markets are very difficult, the fact that Western EU markets are very difficult and costs which are too high. The most commonly indicated threats of no importance were: too high expectations of the workforce and difficult Western EU markets - 19\% each. Interestingly, the lowest percentage of indications were related to strong competition and the gap in technological development $-4 \%$ each.

It is worth mentioning that, in the opinion of the examined service companies of the tourism sector, the liberalisation of the services market has impacted the increase in the value of the export of services. The highest ratio of indications concerning the years 2013-2016 (59\%) was connected with the increase within the range $20-29 \%$, none of the respondents indicated the increase below $10 \%$. Unfortunately, for some of the companies, the realisation of the service exports to the EU markets is also connected with overcoming regulatory (16\%) and administrative barriers (23\%). In the opinion of $29 \%$ of the respondents, barriers are of discriminatory nature.

\section{Conclusion}

Under the conditions of European integration and progressing globalisation, the interest in the international trade of services appears to be increasing. The process is determined by, among others, a considerable growth in the international exchange of goods, which is accompanied by the increase in the value of the related services turnover. At present, services are becoming an indispensable element of goods exchange; they contribute to the increase in the customer value. The growing liberalisation of the services market, creating new possibilities for international exchange, is gaining in importance. Building the EU single services market further facilitates the changes.

The findings of the research among Polish companies providing tourist services in the markets of other EU countries have shown that liberalisation is seen in the context of benefits as well as threats. While the benefits are mainly related to the opportunities for the development of the company, the threats are mainly connected with bureaucracy. It may be stated that providing services, including tourist services, in the markets of other EU countries creates a challenge for Polish companies, especially those from the SMEs sector. The latter can be said of the entities from the business environment which may undertake activity enabling service companies to fully participate in the benefits of the internal market. 


\section{References}

Directive 2006/123/WE of the European Parliament and the Council of 12 December 2006 concerning services in the internal market, L 376/36, 27.12.2006.

Egan, P.M. (2015). Single markets: economic integration in Europe and the United States. Oxford-New York: Oxford University Press.

Europe, the world's No. 1 tourist destination - a new political framework for tourism in Europe (2010). Communication from the Commission to the European Parliament, the Council, the European Economic and Social Committee and the Committee of the Regions, COM/2010/0352. Retrieved from: eur-lex.europa.eu/legal-content/EN/ALL/?uri.

Fabbrini, S. (2015). Which European Union? Europe after the Euro crisis. Cambridge: Cambridge University Press.

Regulation (EU) (1011). No. 692/2011 of the European Parliament and the Council of 6 July 2011 concerning European statistics on tourism and repealing Council Directive 95/57/EC; OJ of the EU, L 192 of 22.07.2011.

Statystyka w dziedzinie turystyki - Statistics Explained - Europa EU (2015). Retrieved from: ec.europa.eu/eurostat/statistics-explained/ index.php/Tourism_statistics/pl (24.04.2017).

Study on the competitiveness of the EU tourism sector in September 2009. Retrieved from: http://ec.europa.eu/enterprise/newsroom/cf/ document.cfm?action=display\&doc_id=5257\&userservice_id=1\&request.id=0.

Sustained growth in international tourism despite challenges, World Tourism Organisation UNWTO, Press Release (17 January 2017). Retrieved from: http://www2.unwto.org/press-release/2017-01-17/sustained-growth-international-tourism-despite-challenges (24.04.2017).

The Treaty on the Functioning of the European Union, Consolidated versions (2012). Official Journal C, 326, 0001-0390. Retrieved from: http://eur-lex.europa.eu/legal-content/PL/TXT/?uri=celex\%3A12012E\%2FTXT (26.10.2012).

Tourism statistics - intra-EU tourism flows -Statistic Explained (April 2017). Retrieved from: http://ec.europa.eu/eurostat/statisticsexplained/index.php/Tourism_statistics_-_intra-EU_tourism_flows (29.07.2017).

World Tourism Day 2017 addresses the power of sustainable tourism for development. Press Release - media (29 September 2017). Retrieved from: media.unwto.org/.../2017.../2017-international-year-sustainable-to (29.07.2017).

Cite this article aS: Dąrowska, A., Janoś-Kresło, M. (2018). Benefits and threats related to the functioning of Polish tourist companies against the background of the liberalisation of the services market. European Journal of Service Management, 1 (25), 67-72. DOI: 10.18276/ejsm.2018.25-08. 